\title{
Botany of Cucumis melo
}

\section{Opinion}

Cucurbitaceae is a family of the genus Cucumis and consists of more than 30 species. Of these known species, the cultivated speciesinclude cucumber (C. sativus L.), melon (C. melo L.) and horned cucumber or kiwano (C. metuliferus E. mey ex Schrad), which are all annual plants. They have large angular leaves, long petioles, simple tendrils, long branched and hirsute stems, and with climbing or trailing growth habits. Cucumis melo is the most polymorphic species which is a character of great importance in taxonomic studies. Several taxonomic studies have attempted to taxonomically subdivide melons into subspecies, botanical varieties or groups. A classification study proposed by Naudin ${ }^{1}$ resulted in the grouping of these species into 10 botanical groups based on the diverse forms. Whitaker \& Davis, ${ }^{2}$ Munger \& Robinson, ${ }^{3}$ Robinson \& Decker-Walters ${ }^{4}$ also contributed to Naudins ${ }^{1}$ classification which remained a basis for melon intraspecific classification with amendments being brought today. These taxonomic studies results to the 7 intra-specific groups of melons known present: agrestis (wild melon), cantalupensis (sweet melon), inodorus (winter melon), flexuosus (snake melon or snake cucumber), conomon (pickling melon), dudaim (mango melon or pomegranate melon) and momordica (snap melon). Africa is considered to be the centre of origin for melon because of the frequent occurrence of wild species of Cucumis with the same basic chromosome number $n=12 .{ }^{5}$ The secondary center of origin of melon is in Turkey, Syria, Iran, Afganistan, India, Turkmenistan, Tadjikistan and Uzbeskistan.China, Korea, Portugal and Spain were also referred as the secondary centres of diversity for these species. Whitaker \& Bemis ${ }^{6}$ also indicated that $C$. melo are found only in eastern tropical Africa south of the Sahara. In addition to the results, Pitrat et al. ${ }^{7}$ reported that wild types are commonly found in the Sudano-Sahelian area Furthermore the secondary centre of diversity stretch from Asia the Mediterran to Japan. Cucumis melo, which came in many different forms and uses, is one of the important horticultural crops worldwide and plays an important role in international trade. The immature and mature melon fruits are used as dessert and vegetables. ${ }^{5}$ Melon seeds are also eaten after being slightly roasted, and is also used to produce edible oils. Pest and different agents, such as bacteria, fungi and viruses are known to provoke diseases and great losses in melons. Their distribution and impact on melon plants vary around the world. Fusarium wilt, powdery mildew, Alternaria leaf blight and gummy stem blight are among the important fungal diseases known. Lecoq et $\mathrm{al}^{8}{ }^{8}$ discussed that some viral diseases that cause economic losses globally are Cucumber Mosaic Virus (CMV), Papaya Ring Spot Virus (PRSV), Watermelon Mosaic Virus 2 (WMV 2), Zucchini Yellow Mosaic Virus (ZYMV), Cucurbit Aphid-Borne Yellows Virus (CABYV), Squash Mosaic Virus (SqMV) and Watermelon Chlorotic Stunt Virus (WCSV).Pests such as the white fly, aphids, leaf miner and the fruit flyare different insect species known to infest melons. Damages caused by insect pest are either direct through insect feeding or indirect through transmission of viral diseases. White flies (Bemisia tabaci) known to transmit Geminiviruses as WCSV, ${ }^{9}$ while aphids are known to transmit both Luteo viruses as $\mathrm{CABYV}^{10}$ and Potyviruses as ZYMV. ${ }^{4}$ Leaf miners (Liriomyza spp.) caused damageon melons
Volume 2 Issue 3 - 2018

\author{
Ismail Bezirganoglu \\ Department of Molecular Biology and Genetics, Erzurum \\ Technical University, Turkey
}

Correspondence: Ismail Bezirganoglu, Department of Molecular Biology and Genetics, Erzurum Technical University, Turkey, Tel 00905072798773 ,

Email ismail.bezirganoglu@erzurum.edu.tr

Received: January 09, 2018 | Published: May 31, 2018

through feeding punctures while it larva bores leaf tissues..$^{10}$ The melon fruit fly (Dacus spp.) also causes severe damage during oviposition of female fly in immature melon fruits. ${ }^{4}$

\section{Acknowledgements}

None.

\section{Conflict of interest}

Author declares that there is no conflict of interest.

\section{References}

1. Naudin C. Essais d'une monographie des especes et des varieties du genre Cucumis. Annales des Sciences Naturelles. 1859;11:5-87.

2. Whitaker TW, Davis GN. Cucurbits: Botany, Cultivation and Utilization. Leonard Hill. 1962.

3. Munger HM, Robinson RW. Nomenclature of Cucumis melo L. Cucurbit Genetics Cooperative Report. 1991;14:43-44.

4. Robinson RW, Decker Walters DS. Cucurbits. CABI. 1997;226.

5. El Tahir IM, Taha Yousif M. Indigenous melons (Cucumis melo L.) in Sudan: a review of their genetic resources and prospects for use as sources of disease and insectresistance. Plant Genet Res Newsl. 2004;138:36-42.

6. Whitaker TW, Bemis WP. Cucurbits. In: Simmonds NW editor. Evolution of crop plants, $2^{\text {nd }}$ edition. UK;1976:64-69.

7. Pitrat $M$, Hanelt $P$, Hammer K. Some comments on interspecific classification of cultivars of melon. Acta Horticulturae. 2000;510: 29-36.

8. Lecoq H, Lot H, Gebre Selassie K. Integrated management of virus diseases in vegetable crops in the open field. Arab J Plant Pathol. 1998;16(1): 3234.

9. Kheyer Pour A, Bananej K, Daffalla GA, et al. Watermelon chlorotic stunt virus from the Sudan and Iran : Sequence comparisons and identification of a whitefly-transmission determinant. Phytopathology. 2000;90(6):629635 .

10. Dogimont C, Bordat D, Pitrat M, et al. Characterization of resistance to Liriomyza trifolii (Burgess) in melon (Cucumis melo L.). Fruits. 1995;50(6):449-452. 